\section{Bacteriological quality of homologous breast milk}

Sir,

In a recent report Carroll et al. ${ }^{1}$ showed that the bacterial colony counts of early drip breast milk did not differ from midstream samples and they concluded that early milk was suitable for milk banks and should not be discarded. We report our findings of 'significant' bacterial counts in early milk samples, since we were interested in the bacteriological quality of breast milk ingested by the mother's own baby.

In a study to investigate the bacterial content of homologous breast milk the first $2-3 \mathrm{ml}$ milk were collected by manual expression into sterile containers before the infant suckled. Quantitative bacterial counts were performed as described. ${ }^{2}$ Ninety samples of expressed breast milk (EBM) were tested from 45 mothers (Figure). The volume of 21 samples was insufficient for satisfactory quantitative counts and only the presence of pathogens could be determined.

Thirty-six $(66 \%)$ of 69 samples had counts $>2500$ organisms $/ \mathrm{ml}$ and altogether 'potential pathogens' were isolated from $14(15 \%)$ of 90 samples of the first $2-3 \mathrm{ml}$ of EBM. Our earlier results ${ }^{2}$ indicated that $33 \%$ of EBM aliquots had counts $>2500$ organisms $/ \mathrm{ml}$ from both hospital and domiciliary donations. It is clear from the figures of Carroll et al. ${ }^{1}$ that $4(20 \%)$ of 20 paired milk samples had 'potential pathogens' by our criteria, ${ }^{2}$ while $9(47 \%)$ of 19 had initial counts at or $>10^{7}$ colony counts/litre. From these bacteriological results it is evident that both groups of mothers in the two reports were providing milk for their own babies which on our previous criteria ${ }^{2}$ we would not give to unrelated babies.

The offspring of our mothers did not show clinical evidence of neonatal infection although clearly they

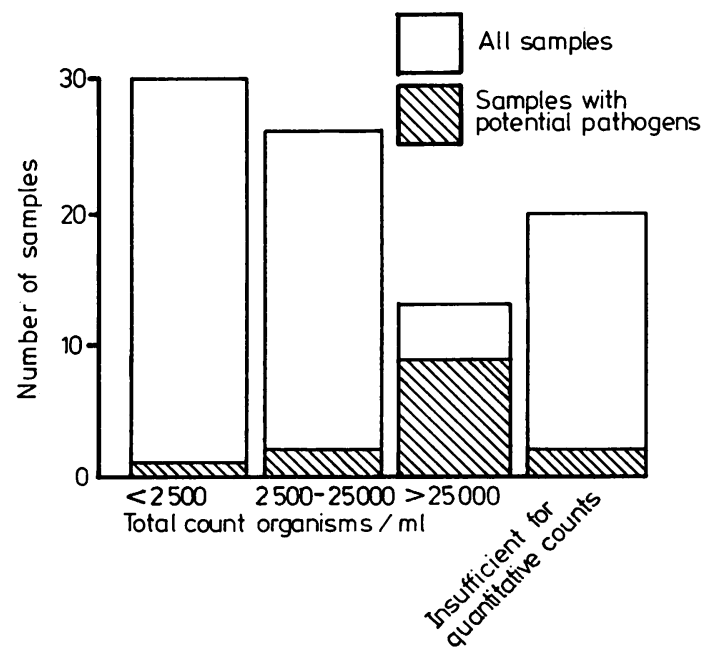

Figure Results of 90 samples of expressed breast milk from 45 mothers. ingested some 'potential pathogens' and large numbers of non-pathogenic organisms. We could not determine whether the origin of the organisms was maternal or non-maternal, but if there were some non-maternal organisms it is unlikely that specific homologous antibodies were present in the ingested milk or colostrum. The mother's own organisms are probably less harmful to her own child because of the antibodies in her milk which reflect her own immunological experience. ${ }^{3}$ Other non-specific protective mechanisms, such as gastric acidity, may also be important in reducing the infective risk of 'potential pathogens'.

Much controversy exists about the relative virtues of pasteurisation and bacteriological screening of donor milk for breast banks, and reservations have been expressed about the use of milk known to contain certain types or numbers of bacteria. Nevertheless it is clear from our data and those of Carroll et al. ${ }^{1}$ that breast-fed infants ingest 'potentially pathogenic', and large numbers of nonpathogenic, organisms without obvious deleterious effects.

\section{References}

1 Carroll L, Osman M, Davies D P. Does discarding the first few millilitres of breast milk improve the bacteriological quality of bank breast milk? Arch Dis Child 1980; 55: 898-9.

2 Davidson D C, Poll R A, Roberts C. Bacteriological monitoring of unheated human milk. Arch Dis Child $1979 ; 54: 760-4$.

3 Gunther M. Cited by E M Widdowson in a symposium report: Protective properties of human milk and the effects of processing on them. Arch Dis Child 1978; 53: 684-6.

D C DAvidson, Vivian Blundell, AND C Roberts Maternity Unit and

Public Health Laboratory, Fazakerley Hospital, Liverpool L9 $7 A L$

\section{Transpyloric feeding}

Sir,

We were very encouraged to read about Elizabeth Dryburgh's experiences with transpyloric feeding. ${ }^{1}$ Early last year Dr Dryburgh came to Leicester to demonstrate her technique and we now use transpyloric feeding in our neonatal unit. It has proved a valuable addition to our existing methods of feeding babies.

To date 38 babies have been fed by this route. Fourteen infants were $<1.50 \mathrm{~kg}$ (range 940-1400 g); 24 infants were $>1.5 \mathrm{~kg}$ (range $1510-4000 \mathrm{~g}$ ). The mean duration of transpyloric feeding was $5 \frac{1}{2}$ (range 1-15) days. The main indication for transpyloric feeding was apnoea or the fear of producing apnoea in very small babies by nasogastric feeding. Respiratory distress syndrome not requiring assisted ventilation was the next most common indication. The following complications have been recorded: 7 infants removed the tube; in one infant the tube became blocked and had to be removed; 5 developed diarrhoea associated with distal placement of the feeding tube (in one of these infants repeated vomiting occurred after resiting the tube and so transpyloric feeding was stopped); 2 developed abdominal distension and bile-stained 